\title{
The Prevention of Gratification in the District Court
}

\author{
Hibnu Nugroho ${ }^{1^{*}}$ \\ ${ }^{1}$ Faculty of Law, Jenderal Soedirman University, Purwokerto, Central Java, Indonesia
}

\begin{abstract}
The criminal act of corruption gives negative impact to all living lines of a nation, the loss occurred not only when the criminal act happened but also give the domino effect until many years later. The courts are one of the spearheads in criminal act court, therefore this institution must be clean and strong against various influence. Some criminal acts of corruption were quite done by the judges; furthermore the question occurred how the criminal act of corruption and prevention model of gratification can be implemented in the district court institutions. The aim of this paper is to determine the criminal act of corruption and gratification model that can be implemented in the district court.
\end{abstract}

\section{Introduction and literature review}

Corruption is a universal problem, according to Transparency International. It affects all sectors of society from construction (France), education (Uganda), police (Malaysia), to parliament (Japan), the judiciary (Brazil, Burkina Faso, Ecuador, Israel and Nepal) and even Church (Greece). [1] Cross-country studies investigate the causes of corruption that have identified several factors which may have an impact on corruption, ranging from structural factors, to institutional, historical, and economic factors. However, there are not many country level studies exploring the causes of corruption in specific contexts. In the case of Indonesia, corruption in this country is likely to be facilitated by a number of factors, such as large amounts of public resources derived from natural resources, vested interests and politically connected networks, poorly paid civil servants, low regulatory quality, and weak judicial independence. In addition, local officials are given wide discretionary power and resources without proper accountability and enforcement mechanisms [2].

Negative consequence from systemic corruption through democratic process and sustainable development legitimate democratic process with reducing the public trust through political process by money politic, distort the decision-making on public policy, and deny the rule of law. Corruption eradication effort has increased significantly which is numbered 821 or 32,10 percent of the total specific criminal case received by the MA RI totaled 2558 cases, this thing can be seen through the annual reports of the Supreme Court in 2013 [3].

Prevention is much better than cure, the maxim applies almost in all the pillars of human life. This also applies to corrupt behaviour, preventing the emergence of corrupt behaviour

* Corresponding author : hibnunugroho@gmail.com 
both individually and groups have same importance to do. Regeneration of corrupt behaviour indicates a failure in the anti-corruption education process in society [4].

Corruption Eradication Commission (KPK) has the ideals of National Integrity System (SIN) in Indonesia. Why this program aspired by the KPK? Because according to KPK, integrity is the key to all things. The higher of the integrity a person, the strength against the virus attack called corruption also becomes stronger. Similarly, with the lower integrity, the virus more easily attack and gnaw. The role of integrity is very important, not only must be owned by individuals but also systems and institutions [5].

The Government in Medium-term National Development Plan (RPJMN) made by Bappenas, in Chapter VII of Law and Apparatus for reference Strategic Plan (RENSTRA) Ministry/Agency, one of them is the national legislation program for a five-year medium period, the stage of national medium development goals and long-term RPJMN III, then the national medium-term development plan for the period 2015-2019, is directed to (a) creating quality and fair law enforcement; (b) increase legal contributions to enhance the nation's economic competitiveness; and (c) raising law awareness in all fields. The problem studied in this article is how are the prevention of corruption and gratification committed in the district court?

\section{Methodology}

The research method of this research is using an empirical juridical approach, specifically in descriptive analytic research. Since this research tries to illustrate the fact about supervision and prevention of gratification in the court environment, so it is used Research and Development analysis.

\section{Discussion}

Clean Indonesia from corruption is a dream and ideals of all people who love Indonesia. For more than a decade, eradication efforts have been carried out despite following the political laws of the ruling government. In present time, the efforts to prevent and eradicate corruption have been done in a balanced way. It has been more than a decade running KPK institutions as the spearhead of corruption eradication noted the regeneration of corruption actors, therefore prevention efforts are also carried out vigorously in all lines of life.

National Integrity System is a program initiated by KPK, this system is like a pillar used to support the building. In order for the firm established building, required three important elements that are foundation, pillars or poles, and roof. Its analogy is to illustrate, the first element is the foundation, in SIN term, analogize as a foundation. The foundation here is a national commitment and noble values owned by the Indonesian. While the pole consists a number of pillars that represent various elements in the state. And finally, the roof is the final achieved result in the form of national integrity.

Each of these pillars should be encouraged in order to carry out their respective roles. For producing an optimal role, each pillar is encouraged to perform [5]:

1.Ensure each pillar runs the role with integrity based on each special equality collaborated with other pillars in developing SIN.

2. Transparency and accountability (governance) in this case, each pillar must apply accountability and transparency, in the form of integrity system implementation, both the main component and the supporting component, ensuring the existence of instruments, processes and structures

3. Capacity. In order to build the integrity system and perform its role in integrity, each pillar must have the capacity to run both of these 
The judicial institution is one of the pillars in implementing the law enforcement, therefore the judiciary must be able to become a truly clean institution from the disgraceful behaviour of its law enforcers. Judicial Corruption is very damaging to the judicial image in Indonesia, some of the practices of Judicial Corruption, such as (1) the intervention of a particular judge who has a special relationship with a particular advocate, often in the form of gratification or bribes, (2) falsification of judgments; (3) speed up or slow the case (4) The rule of weight and lightness of the punishment and (5) the interpretation of the articles of legislation in essence for the decision in accordance with the wishes of certain party [6].

In 2017 the chairman of the Supreme Court declared that the year as a "clean-up" year, the Supreme Court in cooperation with the KPK to exchange information, in this activity successfully arrested two judges and two substitute clerks because the person was caught redhanded for a bribe. Throughout 2017 there were MA personnel and under-disciplinary bodies disciplined as 103 with details of 30 heavy sanctions, 11 medium sanctions, and 62 mild sanctions.

The Supreme Court issued Supreme Notice No. 1 of 2017 on the Implementation of a Tiered Supervision System that sanctions imposed on a judicial apparatus would also drag its superiors if it proved to be not conducting supervisory duties. In addition, the Supreme Court also fielded several people who have been trained specifically as a disguised agent (mystery shopper). The task of the mystery shopper is to infiltrate the various courts to monitor and arrest in case of bribery and sale of cases.

In the Supreme Court Regulation Number 7 of 2016 concerning on Enforcement Work Discipline of Judges to the Supreme Court and the Courts Institution under it concerning matters relating to the prevention of gratification is not regulated, provisions ruling the Whistleblowing System in the Supreme Court and the Judiciary under it regulated in Supreme Court Number 9 of 2016. In its consideration it is mentioned that if found any corruption, collusion and nepotism then every judicial apparatus must report to the Supervisory Board. This is done with the intention that the authority and dignity of the judiciary are maintained, besides the service to the justice seeker community can run well.

In the Regulation Number 9 of 2016 it is mentioned that several principles in the handling of complaints are integrated, all complaints from the first-level court should be incorporated into the Information System application of oversight bodies by both reporters independently and electronically. Objectivity, complaint handling is done objectively not based on the interests. Effective, efficient and economical, that is the complaint handling and follow-up on alleged violations done in an appropriate target, saving in terms of resources, personnel, costs and time take accordance with the applicable regulations. Transparency, all interested parties can know the stages of the complaint handling process and its follow-up. Accountability, the process of handling the adjudication and its follow-up must be accountable to the public in accordance with applicable laws and procedures. Confidentiality, caution in handling complaints is done by maintaining the confidentiality of the reporting identity and reporting materials. The parties, the reporting parties, the reported parties, the related parties and the witnesses shall be treated equally. Non-discriminatory, in the handling of complaints does not distinguish the treatment based on gender, ethnicity, race, religion and class. Independence, free from outside interference and free from all forms of pressure both physically and psychologically. Neutrality, every complaint handling is implemented impartially and is free of influence. Legal certainty, every handling of complaints prioritizes the basis of applicable legislation. The professionalism of the supervisory apparatus performs its duties with expertise. The proportionality of the handling of complaints takes precedence over the interests of the parties in the handling of the complaint. Uphold the independence of the judiciary, in the process of handling complaints as far as possible while maintaining the independence of the judiciary. 
The complainant and reporter in the inspection has the rights regulated in the SEMA, the rights in handling complaints for the complainant is to be protected against the confidentiality of their identity; have the opportunity to be able to give free information without coercion from any party; be informed of the stages of reports / complaints he or she has registered; receive equal treatment and is equivalent to the reported in the examination; shall be entitled to present evidence to strengthen his complaint and receive an inspection report.

The Reported Party has the right to prove that he is innocent by filing witnesses and other evidence; have the opportunity to give free information without coercion from any party, receive equal treatment and be equal to the reporting party in the examination; reserves the right to request an event report; and obtained a certificate stating that the complaint is not proven.

The subject of Supervision and Supervision in the Supreme Court and the Courts under, it is regulated in Perma Number 7 of 2016 in this Perma supervision is divided into two, namely inherent supervision and functional supervision. What is meant by inherent supervision is a series of activities that are as continuous control carried out by the direct superior to the under the preventive or repressive so that the implementation of the duties of the subordinate is running efficiently in accordance with the activity plan and the provisions of applicable legislation. Whereas the supervision functional is the surveillance conducted by officers who are given the task and function specifically to carry out the surveillance in the Supreme Court.

Supervision and guidance of direct supervisors are a series of activities undertaken by each structural office manager to develop continuously and control subordinates directly under it to perform their duties effectively and efficiently and to behave in accordance with the code of ethics of the judicial apparatus and the provisions of legislation, as well as the applicable invitations.

The responsibility of the direct supervisors as regulated in this provision is to carry out the supervision and guidance and execution of duties as well as behaviour of subordinates both inside and outside the office continuously and seek the availability of work facilities or systems based on the authority held, so that the execution of the tasks runs in accordance with the applicable provisions.

The minimum supervisory criteria carried out are monitor, observe and check the implementation of the tasks to run in accordance with the plans and provisions that apply in a useful and effective manner; in addition, the head also requests reports and accountability for the performance of subordinate duties; further identify and analyse the symptoms and irregularities and errors that occur, determine the cause and effect and how to overcome them; formulate follow-up appropriate steps in accordance with their authority as well as with respect to the authority of related officials/institution and consult to the direct supervisor in stages, in order to improve the quality of supervision done.

On the task of coaching the head will provide direction regarding the division of tasks, functions and authority of subordinates within the organizational structure under his control periodically; establishing and approving subordinate performance goals and providing assessment and evaluation of the task performance of subordinates; explaining, making and agreeing procedures or how the implementation of work or activities that are considered less clear or not specially regulated and build subordinates in order to carry out their duties properly.

Direct supervisors who do not carry out supervisory duties and direct coaching has committed a violation with the threat of administrative sanctions with mild, moderate or heavy categories. Forms of mild sanctions are in the form of oral reprimands, written warning and in the form of dissatisfaction in writing.

Sanctions are being imposed is a delay of periodic salary increase of 1 year; postponement of promotion for a maximum of 1 year; exemption from non-hammer office/judge no later 
than 6 months; transfer to another court with a lower grade and cancellation or suspension of promotion. The heavy sanction that can be addressed is in the form of exemption from nonhammer office/judge for more than 6 months; demotions at a lower rank for a maximum of 3 years; dismissed with respect and dismissed with no respect.

The provision has been made by the Supreme Court as the supreme body responsible for the behaviour of judges and personnel in institutionalized courts has been made completely, but in practice in the field still appears the existence of deviant behaviour both done by the judges and other personal who are part of a court.

The effectiveness of a regulation is inseparable from its law factors, its law enforcement factors, tools factors, community and cultural factors [7]. The prevention of gratification in the court environment through tightening of internal regulations of the Supreme Court in the form of inherent supervision, and the imposition of sanctions as an effort called "clean up" indicates that the level of provision is sufficient. The factor of supporting facilities in the form of system of room and order which made in such a way as to minimize direct contact between stakeholders with the judge has also been done.

In the process of law enforcement in the court, the parties consist of justice seekers, advocates, judges, deputy registrar and if in criminal justice, then the attorney general are added. In the process of law enforcement, each side brings its own culture in the process of repeated interaction often raises the habits that are conscious or not lead to the behaviour of gratification. The gratification mode in the court can come from the party who is in litigation but it is not likely to come from the judge who handles the case, on the other hand there is the clerk of the case has a role large enough to be an intermediary or as an initiator in the verdicts transaction. In the outside of court that has important role is the advocates.

Gratification as well as corruption can not be separated with the moral issues of the parties concerned, in this case the judge becomes the key. The Judicial Commission appealed [8], to the judges to stay clear from bribery and gratification, so that the public will respect the judiciary. Giving sanctions and rewards to the judges should be done in a simultaneous way, as judges are not only encouraged to improve the scientific side but also need to balance the strength of the value and ethics of the legal profession or transfer of value.

\section{Conclusion}

The prevention of criminal acts of corruption and gratification conducted in the District Court institutions should be carried out in a simultaneous manner and involving the parties involved in the handling of cases, but the role holders to prevent corrupt behavior and the emergence of gratification are the development of self-integrity for judges, clerks and courts employees generally.

The participation of the community as a watchdog for the enforcement of an honest, fair and transparent system of law enforcement is an essential part of the effort to clean up the non-corrupt judiciary. Therefore, the public should always supervise the performance of the judiciary in order to create a clean and authoritative judiciary.

\section{References}

[1] G. Ksenia, J. Financial. Crime., 15, 223 (2008)

[2] U4NO. Causes of corruption in Indonesia. https://www.u4.no/publications/causes-ofcorruption-in-indonesia.pdf

[3] E. As'adi., J. Dinamika. Hukum. 15, 231 (2015)

[4] H. Nugroho, Optimalisasi Pencegahan dan Penindakan Tindak Pidana Korupsi menuju era Indonesia Bebas Korupsi. Research report. (2015) 
[5] KPK 2012, Jalan Berliku memberantas Korupsi (Laporan Tahunan KPK tahun 2012). Jakarta : KPK, hlm.22

[6] F. Namakule. Peradilan bersih anti korupsi. https://www.kompasiana.com/namakule/598c6d0f835be71056798bb2/peradilanbersih-anti-korupsi

[7] S. Soekanto. Faktor-Faktor yang mempengaruhi Penegakan Hukum (PT. Raja Grafindo Persada, Jakarta, 2008)

[8] A. Mardatillah. Kasus Suap-Gratifikasi Mendominasi di Sidang-Sidang MKH. http://www.hukumonline.com/berita/baca/lt5a4dd59fad9f4/kasus-suap-gratifikasimendominasi-di-sidang-sidang-mkh 